\title{
Description in course of mathematical methods for physics and possible development of course program
}

\author{
Sujito Sujito 1, 2, a *, Liliasari Liliasari ${ }^{1, b}$, Andi Suhandi 1, c, Edy Soewono ${ }^{3, d}$ \\ ${ }^{1}$ Universitas Pendidikan Indonesia. Jl. Dr. Setiabudi No. 229, Bandung 40154, Jawa Barat, Indonesia. \\ 2 Universitas Negeri Malang. Jl. Semarang No. 5 Malang, 65141, Jawa Timur, Indonesia. \\ ${ }^{3}$ Institut Teknologi Bandung. Jl. Ganesa No. 10 Bandung, 40132, Jawa Barat, Indonesia \\ asujito@upi.edu, bliliasari@upi.edu, candi_sh@upi.edu, desoewono@math.itb.ac.id \\ * Corresponding Author.
}

Received: 25 November 2020; Revised: 12 January 2021; Accepted: 30 January 2021

\begin{abstract}
The essence of mathematics is a thought process in constructing, applying abstract ideas, and their logical interrelationships. This process is essential in solving quantitative and qualitative physics problems, where abstract ideas are required to represent physical phenomena. This study aims to give detail description of the process of mathematical methods for physics lectures. Improvement in pre-service physics teachers' critical thinking is designed to strengthen their critical thinking and problem-solving skills. The methodology of research is qualitative descriptive. The research subjects were 97 preservice physics teachers who had followed the mathematical methods for physics courses and teaching lecturers. Data collection consisted of questionnaires, and interviews. Observations are needed for describing the implementation of mathematical methods for physics courses, document analysis, and data collection, including lesson plan and assessment. The results showed that mathematical methods for physics courses need improvement in the learning process. It is concluded that lecture activities integrating computers into physics and mathematics are necessary to be implemented. It is expected that the program will improve students' ability in problem-solving, critical thinking skills, communication, digital era literacy, creative and innovative creations, and group work. Specifically, implementation of the program in the ordinary differential equations course can provide learning experiences to students regarding the process of reasoning in physics using mathematical principles.

Keywords: mathematics methods for physics; classic phenomenom; Computer Aided Design model
\end{abstract}

How to Cite: Sujito, S., Liliasari, L., Suhandi, A., \& Soewono, E. (2021). Description in course of mathematical methods for physics and possible development of course program. Momentum: Physics Education Journal, 5(1), 73-84. https://doi.org/10.21067/mpej.v5i1.5184

\section{Introduction}

Physics as a science has developed since the beginning of the 14th century (Branchetti et al., 2019). Together with biology and chemistry, Physics is included in the group of natural sciences (Doran, 2017). Studying physics is concerned with finding out about the phenomena of the universe. Objects of the universe are studied as a whole, thoroughly, integrated, logically, and regularly to find a causal relationship. The study concerns the mastery of facts, concepts, principles, and the process of inquiry (Redfors et al., 2014). Physics studies factual natural phenomena, either in the form of facts or events and their causal relationships (Chassy \& Jones, 2019). Physics education is expected to be a vehicle for students to study themselves and their environment and the prospects for developing their application in everyday life (Hasim et al., 2020; Pratiwi et al., 2019). Therefore, students are equipped with a variety of supportive knowledge, such as courses in mathematical 
methods for physics. The goal of this course is to provide students with many abilities including (a) proof and reasoning as fundamental aspects of mathematics, (b) mathematical investigation, (c) argument development, and evaluation; (d) selection and use of various types of reasoning and proof.

However, students do not understand the role of mathematics in learning physics. The results of interviews with physics teaching staff showed that students still did not understand the position and role of mathematics in physics. Students still complain about the functions and benefits of mathematics in physics. Learning innovation still cannot be implemented in learning mathematical methods for physics. Thus, they use a simple learning model without involving technology. The development of science and technology in the 21st century creates new challenges in the world of education (Gifford \& Finkelstein, 2020; Hu et al., 2019). Learning experiences a shift in both characteristics and learning models (Odden et al., 2019). The theme of curriculum development shifts to produce people of creative, innovative, productive, and effective. Students are expected to have an attitude in making decisions, integrated skills, and knowledge (Docktor \& Mestre, 2014). Innovation in learning is adapted to the demands of educational changes in the millennial era in welcoming the industrial revolution era 5.0.

Besides, one of the indicators of graduate quality is the quality of lectures supported by learning outcomes by utilizing information and communications technology (ICT) (Hasim et al., 2020). Output competencies must be supported by learning that strengthens student productivity and creativity through skills of critical thinking and communication (Gosper \& Ifenthaler, 2014; Mota et al., 2019). In implement the learning process, the main subjects need to be framed by innovative learning outcomes (Young et al., 2019). Learning is not only limited to school but many other relevant sources. Therefore, this article describes the conditions of the mathematical method in learning physics and how to develop a mathematical method for physics learning which is carried out in the Physics Department.

The research aims to describe the process description of mathematical methods for physics lectures and to find opportunities to develop lecture programs to improve critical thinking and problem-solving skills of pre-service physics teacher's. The advantages of this study are (1) measuring the implementation of the mathematical methods for the physics lecture process; (2) being more responsive to the learning environment when interacting with students, colleagues, and the community; (3) the results can be used as an evaluation of lecturers in carrying out learning.

\section{Method}

Focus

Observations of mathematical methods for physics course are focused on: (1) observing the process of implementing learning for pre-service physics teachers' in class; (2) collecting data through questionnaires to get student responses; (3) analyzing curriculum documents and Semester Learning Plans; (4) collecting data through documentation regarding assessment instruments and assessment results (Williams, 2018).

Subject

The research activity is carried out at a tertiary institution that organizes the Physics Education Study Program. The research subjects consisted of; (1) there are two lecturers of mathematical methods for physics, (2) Students who have taken the course of mathematical methods for physics, namely levels 3 and 4 . The number of students who filled out the questionnaire was 97 students.

\section{Technic of Data Collection}

Data collection was carried out through non-tests in the form of: (1) Questionnaires given to students to be filled in. Questionnaires to students to explore how students respond to mathematical methods for physics courses, and to determine students' interests and difficulties in taking lectures (Marton \& Pong, 2005). (2) Observations intended to photograph the implementation of mathema- 
tical methods for physics lectures (Docktor \& Mestre, 2014). (3). Interviews with two mathematical methods for physics lecturers to know student readiness and lecturers' difficulties in facilitating classes. Interviews were conducted on students in levels 3 and 4 who had taken these courses (Walsh et al., 2019). Another purpose is to synchronize the answers given by students with the results of the questionnaire. (4) Document analysis. This step aims is to determine the alignment between planning programme and the implementation of learning in class. Another objective is to describe the readiness of students. Also, document analysis is intended to cross-check the results of interviews and questionnaires filled out by students (Almalki, 2016). In this research, an analysis was also carried out on documents related to learning and learning activities (Creswell \& Creswell, 2017). The documents in question are test instruments, grades, lesson plans, assignments, and test results for courses in mathematical methods for physics (Bollen et al., 2015).

\section{Technic of Analysis Data}

The data obtained were analyzed as follows: (1) Data analysis obtained from the questionnaire results was carried out quantitatively by calculating the number of frequencies on the likert scale category of each item (Marton \& Pong, 2005), (2) Data analysis from observations and interviews was conducted descriptively (Docktor \& Mestre, 2014; Walsh et al., 2019), (3) The research data were tabulated into the research finding tabulation.

\section{Steps of Research}

The steps taken in this study are: (1) the pre-implementation stage of the field study. This stage involves the preparation and determination of students to be the subjects. Instrument preparation includes questionnaires, observation guides, interview guides, and document analysis. Document analysis was carried out by asking the lecturers for curriculum, lesson plan, assignments, assessment instruments, and test results. This analysis is for the needs of the lecture program development design plan. (2) The field study implementation stage. This stage is carried out by observing the lecture process in class, giving questionnaires to students, interviewing lecturers, interviewing students, and analyzing documents. (3) The final stage is theory development based on the data obtained (Creswell \& Creswell, 2017).

\section{Results and Discussion}

\section{Mathematical methods for physics Lecturer Profile}

Mathematical methods for physics courses are split into two, namely mathematical methods for physics I with three credits and course code PFIS6006, and Mathematical methods for physics II with three credits and course code PFIS6007. The lecture profile is as in Table 1.

\section{Field Findings of interview}

\section{Lecturer interview}

The lecturer interviews were related to the lecturers' difficulties in facilitating lectures. Recapitulation of interviews between lecturers and interviewers is as follows:

1. Q: What are the difficulties in facilitating Mathematical methods for physics lectures?

A: Several conditions must be applied to achieve learning goals that have not been achieved optimally. The main obstacle is the limited time and the amount of material taught

2. Q: What difficulties do students experience?

A: To give meaning to physical cases, students only plug and play mathematical formulas

3. Q: What forms of learning effort do students take?

A: In the lecture process, students can interact with other groups and convey ideas and concepts of mathematical methods for physics. However, the problem is that some students cannot connect the concepts of physics and mathematics tools

4. Q: Have students been equipped with 21st-century skills in Mathematical methods for physics courses? 
A: Yes. Students are directed to be skilled in critical and creative thinking linking previous knowledge with the information obtained

5. Q: Have you directed students to think critically, creatively, collaboratively, and inventively?

A: Yes. Students should experience the ability to think critically and creatively by giving them problems related to everyday phenomena. Students have not yet collaborated, but they have done it both with friends and seniors. To think inventively, I think it is because students are willing to accept work results from friends

6. Q: Have the mathematical methods for physics courses equipped students with ICT literacy and Cyber internet?

A: Not yet, because its use requires preparation, including internet use, which requires adequate infrastructure

7. Q: How are students interested in mathematical methods for physics courses

A: During the lecture process students are interested in discussing physical phenomena, hopefully in the future students will master physics. It can be seen that students are eager to seek information from several sources related to the material

8. Q: Does starting to study mathematical methods for physics always begin with studying everyday phenomena?

A: Not yet

Table 1. Brief description of mathematical methods for physics

\begin{tabular}{|c|c|}
\hline Aspect & Brief Description \\
\hline \multirow[t]{3}{*}{ Learning outcomes } & Mathematical methods for physics I \\
\hline & $\begin{array}{l}\text { Mastering the essential concepts of ordinary differential equations, multiple integrals, } \\
\text { vector analysis, calculus of variations, and infinite series and applying them to solve math } \\
\text { or physics and computational problems related to them appropriately, systematically, } \\
\text { independently, responsibly, and utilizing science and technology developments. } \\
\text { Mathematical methods for physics II }\end{array}$ \\
\hline & $\begin{array}{l}\text { Mastering the essential concepts of Fourier series, special functions I (gamma, beta, } \\
\text { etc.), special functions II (Legendre, Bessel, etc.), Partial Differential Equations, and } \\
\text { Integral Transformations and being able to apply to solve mathematical or physical } \\
\text { problems related appropriately, systematically, independently, responsibly, and utilizing } \\
\text { science and technology developments. }\end{array}$ \\
\hline \multirow[t]{4}{*}{ Study material } & Mathematical methods for physics I \\
\hline & $\begin{array}{l}\text { Ordinary Differential Equations: PD with separate variables, first-order linear PD, exact PD, } \\
\text { homogeneous second order linear PD; Double Integral: Double integral, triple integral, } \\
\text { changing variables; Vector Analysis: Vector algebra, vector differentiation, operators } \\
\text { (gradient, divergence, rotation), line integrals, Green's theorem, divergence theorem, Stokes } \\
\text { theorem; Infinite Series: Geometry series and other infinite number series, convergence, } \\
\text { power series; calculus of variations. }\end{array}$ \\
\hline & Mathematical methods for physics II \\
\hline & $\begin{array}{l}\text { Fourier series: periodic functions, mean values, sin-cos Fourier series, complex Fourier } \\
\text { series. Special Functions I: Gamma function, Stirling approximation formula, Beta } \\
\text { function, error function. Solving Differential Equations using the power series method, } \\
\text { Frobenius method. Special Functions: Legendre polynomial, Bessel function, Laquerre } \\
\text { polynomial, Hermite polynomial. Partial Differential Equations: Application of the } \\
\text { variable separation method to the Laplace equation, the wave equation. Integral } \\
\text { Transformation: Laplace transform, Fourier transform. }\end{array}$ \\
\hline Learning Methode & Lectures, Discussions, Assignments \& Presentations \\
\hline Learning Media & PowerPoint (PPT) \\
\hline Assignment & Writing papers, logbooks \& presentations \\
\hline Assessment & Observations, presentations \& tests \\
\hline
\end{tabular}

\section{Students interview}

The results of interviews with level 3 and level 4 students who have taken courses are as follows. 
1. Q: Do you enjoy taking mathematical methods for physics courses?

$\mathrm{S}$ : Yes, because just enjoy following this course

2. Q: What benefits do you get after studying mathematical methods for physics?

$\mathrm{S}$ : Understand math tools used in physics

3. Q: What are your difficulties with learning mathematical methods for physics?

$\mathrm{S}$ : Gives meaning to the equations obtained in mathematical calculations

4. Q: What kind of effort do you put into studying mathematical methods for physics?

$\mathrm{S}$ : Learn from various kinds of literature

5. Q: Do the mathematical methods for physics concept being studied provoke you to think?

$\mathrm{S}$ : Yes, think not only critically but also creatively to find the right solution

6. Q: Are you interested follow courses on mathematical methods for physics?

S: Yes, very much,

7. Q: What would you like to gain from your mathematical methods for the physics course?

S: Studying physics further as a preparation for taking further courses and further studies

8. Q: Do you want to study mathematical methods for physics in a Laboratory?

$\mathrm{S}$ : It needs to be supported by an adequate computational laboratory

The results of interviews with lecturers and students showed almost the same opinion. Students claim to have high enough enthusiasm to attend lectures. However, the students' concept of mastery ability is still inadequate. The use of information technology is still minimal and less practical because it is influenced by the limited number of learning media.

The interviews with students at different levels obtained information that students like to take courses in mathematical methods for physics. This subject is related to everyday life. This course adds knowledge, insight, and curiosity about physical phenomena. However, this course's subject matter has a difficulty level that is quite complex, abstract, difficult to observe, references that are difficult to understand, and there are no learning media. The positive thing about interviews with students is that they get help by reading information from the website when students have difficulty reading literature. The concept of mathematical methods for physics provoked them to know more things.

The findings obtained from the interview with students and lecturers, namely lecture is not yet equipped with 21st-century skills and not yet integrating computers into learning material. Learning objects have not been maximally achieved and tend to "plug and play" mathematical equations. An interesting phrase from some students is "when I passed the mathematical methods for physics course, I still did not know the usefulness of the equations studied". This fact presents a challenge as a student's existence in front of his friends. In other cases, it was revealed that the course of mathematical methods for physics is a difficult subject to learn. This subject requires problems to facilitate understanding. Mathematics is linked with physics problems to be easy to learn. The findings were obtained from the analysis of learning materials. Teaching materials have not integrated modeling and there is no image representation showing the formed fields. The taking of the substance of teaching materials is less contextual and there are no illustrations, especially in the form of 2-dimensional or 3-dimensional images.

\section{Field Findings of the questionnaire}

The results of student questionnaires regarding the process of implementing mathematical methods for physics courses can be seen in Table 2 .

The findings obtained from this study are based on a student questionnaire, as such Table 2 . Existing teaching materials do not help student learning independently. The implementation of concepts is not in contextual cases so that it is less supportive of interpreting and developing concepts. Students prefer learning materials from outside and do it in groups. More detailed, sequential, and structured teaching materials are needed. Based on the result of observation. Lectures are too mathematical and not applicable so that the physical symptoms are not visible. In other cases, the use of text teaching materials is very minimal. Students are more looking for their literature and not contextual. 
Table 2. The result of student questionnaires

\begin{tabular}{|c|c|c|c|}
\hline \multirow[t]{2}{*}{ Number } & \multirow[t]{2}{*}{ Statement } & \multicolumn{2}{|c|}{$\begin{array}{l}\text { Predisposition } \\
\%\end{array}$} \\
\hline & & Agree & No \\
\hline 1. & $\begin{array}{l}\text { The lecturer describes the mathematical methods for the physics course at the } \\
\text { beginning of the lecture }\end{array}$ & 94.7 & 5.3 \\
\hline 2. & $\begin{array}{l}\text { In delivering mathematical methods for the physics course material, lecturers use } \\
\text { a variety of teaching methods }\end{array}$ & 79.7 & 20.3 \\
\hline 3. & $\begin{array}{l}\text { The lecturer teaching method makes you motivated to take mathematical } \\
\text { methods for physics courses }\end{array}$ & 87.3 & 12.7 \\
\hline 4. & $\begin{array}{l}\text { In Mathematical methods for physics lectures, lecturers use a variety of learning } \\
\text { media }\end{array}$ & 71.5 & 28.5 \\
\hline 5. & The media used makes it easier to understand mathematical methods for physics & 82.9 & 17.1 \\
\hline 6. & $\begin{array}{l}\text { The media used is interesting and inspires enthusiasm for learning mathematical } \\
\text { methods for physics }\end{array}$ & 73.5 & 26.5 \\
\hline 7. & $\begin{array}{l}\text { The media used is to present material that is coherent, well organized, and } \\
\text { scheduled }\end{array}$ & 86.2 & 13.8 \\
\hline 8. & $\begin{array}{l}\text { Mathematical methods for physics courses are often invited to solve problems } \\
\text { related to everyday phenomena }\end{array}$ & 19.1 & 80.9 \\
\hline 9. & You are given the opportunity freely by the lecturer to present a lecture material & 88.6 & 11.4 \\
\hline 10. & $\begin{array}{l}\text { Mathematical methods for physics Lecture, so far, facilitates you to study } \\
\text { concepts from various literature }\end{array}$ & 77.2 & 22.8 \\
\hline 11. & $\begin{array}{l}\text { I prefer to learn to use literature from foreign sources than those developed by } \\
\text { lecturers }\end{array}$ & 85.2 & 14.7 \\
\hline 12. & $\begin{array}{l}\text { The teaching materials developed by the lecturers did not help me in studying } \\
\text { independently }\end{array}$ & 63.3 & 36.7 \\
\hline 13. & You are facilitated to interpret the concepts & 87.2 & 12.8 \\
\hline 14. & $\begin{array}{l}\text { Mathematical methods for physics lectures have been helping to develop the } \\
\text { ability to imagine }\end{array}$ & 77.6 & 22.4 \\
\hline 15. & $\begin{array}{l}\text { Mathematical methods for physics courses have facilitated you to carry out an in- } \\
\text { depth analysis of everyday phenomena }\end{array}$ & 66.6 & 33.4 \\
\hline 16. & This course helps me develop my skills to work in groups & 80.8 & 19.2 \\
\hline 17. & In starting learning, lecturers always bring cases related to daily life & 51.3 & 48.7 \\
\hline 18. & $\begin{array}{l}\text { You prefer to learn Mathematical methods for physics starting with everyday } \\
\text { phenomena }\end{array}$ & 44.7 & 55.3 \\
\hline 19. & You feel challenged to solve every problem in mathematical methods for physics & 83.9 & 16.1 \\
\hline 20. & You feel enjoy when you take mathematical methods for physics lectures & 61.9 & 38.1 \\
\hline 21. & $\begin{array}{l}\text { You feel motivated by the lecturer to do your best in mathematical methods for } \\
\text { physics courses }\end{array}$ & 92.5 & 7.5 \\
\hline 23. & You feel that mathematical methods for physics are a difficult subject & 84.7 & 15.3 \\
\hline 24. & You have difficulty understanding mathematical methods for physics concepts & 77.6 & 21.4 \\
\hline 25. & $\begin{array}{l}\text { You are interested and excited about taking mathematical methods for physics } \\
\text { courses }\end{array}$ & 82.5 & 17.5 \\
\hline
\end{tabular}

The results of student questionnaires indicate that students are not enthusiastic about the lecture process. This is because they are not ready to learn, lack reference books and learning resources. Besides, the lecture has not used learning media and spatial thinking skills. Students become passive and do not respond in attending lectures. Lecturers are superior and ask students to do assignments, group discussions but not supervised, diaries and papers.

\section{Field findings of analysis documents}

The analysis of mathematical methods for physics documents in the lecture description is written using simulation as a learning medium. The learning method consists of lectures, discussions, assignments, and presentations: learning media using online media through SIPEJAR online, and PowerPoint. 


\section{Development theory}

\section{Classic phenomenon}

This study shows that mathematics is essential in mastering physics concepts and solving physical phenomena can be solved using a mathematical approach. Understanding of physical phenomena is very important in mastering the concept of physics (Barzilai \& Eilam, 2018). However, it takes a mathematical concept. This will also lead to understanding to understand new concepts that are based on previous concepts. Students use conceptual representations to construct, interpret, and transform physical systems in playing the role of physical phenomena (Klein et al., 2018; Li \& Singh, 2018). Perfect drawing requires an understanding of the development process components in solving physics problems and the ability to easily transform the problem into an explicit representation (Treagust et al., 2017). Students in physics courses are asked to learn tools that are relevant to physics and develop in the context of physics. Various kinds of research that study the relationship between physics and mathematics have been carried out to find solutions or effective ways to solve physics problems (Hill \& Sharma, 2015; Kjeldsen \& Lützen, 2015).

\section{Characteristics of Mathematical Integration in Physics}

In several scientific disciplines, mathematics and physics are interrelated and support each other both in terms of objectives and material structure (Redish \& Kuo, 2015). The main objective of learning physics is to improve students' scientific literacy abilities, including conceptual understanding, process skills, and problem-solving abilities (Ceuppens et al., 2018). For this goal, physics learning not only provides an understanding of the concept of science but should understand how science processes, how reasoning is in science, and the epistemological status of scientific knowledge that can be claimed to be proven and not proven (Deprez et al., 2019; Kneubil \& Robilotta, 2015). Meanwhile, Redish and Kuo explain that mathematics lies in logic and creativity, and mathematics is a pattern and reciprocal relationship between variables (Klein et al., 2019; Redish \& Kuo, 2015).

Galileo Galilei argues that the integration of mathematics and science has occurred for a long time throughout history. Mathematics is the primary language of science, and the language of mathematical symbols has been used for a long time and is very useful in expressing scientific ideas. This view reflects that mathematics and science are complementary because many concepts in mathematics are indispensable for understanding science material (López-Gay et al., 2015). Mathematics and science overlap. For example, the process of observation and data collection in science is incomplete without using mathematics to analyze data quantitatively and explain the relationships between variables in making conclusions.

Therefore, an interdisciplinary approach, such as mathematical methods for physics teaching materials. It can attract Physics students to study mathematics (Pospiech et al., 2015). Teacher organizations from various disciplines provide support and state the value and need for an interdisciplinary learning approach. This study's findings indicate that there are still some significant challenges and hinder activities in implementing integrated learning, such as issues of classroom management, integration learning materials, disparities in content knowledge from teachers, and limited learning time. In line with that, Bajracharya et al. (2019), found that the skills learned in private cannot be transferred effectively in solving other problems. They become hesitant to convey it in public (Bajracharya et al., 2019).

This condition shows that the reflection of a fact can provide meaning. The skill to transfer the form of representation is an indicator of mathematical abilities developed through learning mathematical methods for physics (Branchetti et al., 2019). Knowledge transferability can be seen from understanding in displaying data in diagrams and interpreting (Schermerhorn \& Thompson, 2019; Sutopo \& Waldrip, 2014). Working with data, analyzing data, and displaying data can improve students' ability to understand and communicate all forms of representation (Mešić et al., 2019). Developing an understanding of graphs and interpretation skills require experience with real data. The use of graphs is easier and stronger for students to understand than the explanation of mathematical equations (Deprez et al., 2019). The contribution of graphical representations is very 
meaningful because it is practically impossible to overcome or reach the target curriculum with a lot of content (overload) without using graphical representations (Erol \& Çolak, 2020).

\section{Development program in the future}

Based on various kinds of problems, the program plans that have been successfully accumulated focus more on developing lecture programs. The analysis of teaching materials such as Tables 3 revealed that the content of mathematical analysis techniques presented is under the curriculum. However, still, only a few applications of the basics of mathematical analysis are presented. The presentation techniques vary widely: some begin with the concept of physics into mathematical and analytical concepts; others start from the application of mathematical analysis; introduction first, then continues with examples of its application in the case of physics; and with a discussion of the concept of physics and the application of mathematical analysis. The practice questions used are an effective analysis and do not provide much practice in their application.

Based on the facts presented, it is urgent to design a lecture program by including a computer as an additional supplement (Saprudin et al., 2020). Teaching materials support the lecture presentation to encourage the improvement of logical thinking skills, mathematical communication, creative thinking, critical thinking, procedural attitudes, and literacy in the Cyber Psychical System (CPS) Dispatching (Taleyarkhan et al., 2018). Moreover, when the world is entering the era of industrial revolution 5.0, it demands everyone to balance soft skills, hard skills, and meta-skills. Mastery of exact science plays an important role in increasing students' capacity (Jensen et al., 2017). The key to success in preparing students for the era of the 5.0 industrial revolution is students' increased ability to solve problems, critical thinking, digital literacy communication skills, creative and innovative creations, and the ability to work (Husnaini \& Chen, 2019). Ironically, many teachers still position students as objects, not as individuals whose potential must be developed.

Table 3. Problems and Program Plan

\begin{tabular}{|c|c|c|}
\hline Number & Problems & Development Program Plan \\
\hline 1. & $\begin{array}{l}\text { Teaching materials are uninteresting, } \\
\text { boring, and less oriented to equip } \\
\text { students with } 21 \text { st-century skills. }\end{array}$ & $\begin{array}{l}\text { Compilation of learning tools involving modern } \\
\text { technology, computers, multimedia, and modeling in an } \\
\text { integrated manner with attention to the characteristics of } \\
\text { Mathematical methods for physics }\end{array}$ \\
\hline 2. & $\begin{array}{l}\text { Lack of understanding of pre-service } \\
\text { physics teacher regarding the } \\
\text { development of contextual materials }\end{array}$ & $\begin{array}{l}\text { Development of debriefing programs for students as pre- } \\
\text { service physics teachers regarding the development of } \\
\text { contextual teaching materials }\end{array}$ \\
\hline 3. & $\begin{array}{l}\text { Lack of provisioning in a systematic and } \\
\text { integrated manner regarding learning } \\
\text { assessment }\end{array}$ & Provides provisioning regarding learning assessment \\
\hline
\end{tabular}

Therefore, it is necessary to develop teaching materials to improve critical thinking skills in solving implementation of mathematical conceptual in physics problems. Learning ordinary differential equations material will be able to provide learning experiences to students regarding the process of reasoning in physics using mathematical principles (Klein et al., 2019). The habit of mind with integrated mathematics and physics teaching materials will provide the ability to think in making decisions and taking action.

The Computer-Aided Design (CAD) model is a cognitive apprenticeship program adopted from the vocational field. This program is to develop student skills in solving problems related to assignments. Students can develop and utilize the assistance and use this model by proposing several aspects, namely: context, activities, access to performance and modeling processes, multiple roles and perspectives, collaboration, coaching and scaffolding, reflection, articulation, and assessment integrated with the assignment (Bajracharya \& Thompson, 2016; Nielsen \& Nielsen, 2019). In the context, the component is interpreting the content of changes in physics and authentic principles, namely how to relate content to the real world, and interpreting activities and participation carried out by students through dialogue using quality mathematical equations. 
Activities carried out in the student community can interpret, reflect, and shape meaning, including paying attention to the cognitive distribution related to all interested parties. In the process of making teaching materials, it can be done using the help of computer programming languages (Matlab, Mathematics, etc.), Autocad, CorelDraw, etc. (Ryan et al., 2016). An example of teaching materials that will be made with computers is to include animation in teaching materials. Animation can be done using a programming language and computer language assistance for designing.

\section{Conclusion}

This study succeeded in photographing and describing mathematical methods for physics courses, including preparation, process, and after. The conclusion that can be drawn as a follow-up to this research is that a mathematical method in physics courses requires a 21st-century capabilityoriented learning development program for pre-service physics teachers. The program is needed to overcome student learning difficulties and improve critical, creative, collaborative, and communicative thinking skills. This approach explores scientific facts but more importantly the use of mathematical language to make physical phenomena more meaningful. For this reason, some suggestions that can be put forward for consideration are (1) mathematical methods for physics material is quite complex so that it requires appropriate learning media for each sub-material studied, (2) triangulation techniques are needed in data collection for cross-checking then analyzed the causes and effects of the findings in more depth, (3) in-depth interviews were conducted with all stakeholders involved in learning mathematical methods for physics.

\section{References}

Almalki, S. (2016). Integrating quantitative and qualitative data in mixed methods researchchallenges and benefits. Journal of Education and Learning, 5(3), 288. https://doi.org/10.5539/jel.v5n3p288

Bajracharya, R. R., Emigh, P. J., \& Manogue, C. A. (2019). Students' strategies for solving a multirepresentational partial derivative problem in thermodynamics. Physical Review Physics Education Research, 15(2), 020124. https://doi.org/10.1103/PhysRevPhysEducRes.15.020124

Bajracharya, R. R., \& Thompson, J. R. (2016). Analytical derivation: An epistemic game for solving mathematically based physics problems. Physical Review Physics Education Research, 12(1), 010124. https://doi.org/10.1103/PhysRevPhysEducRes.12.010124

Barzilai, S., \& Eilam, B. (2018). Learners' epistemic criteria and strategies for evaluating scientific visual representations. Learning and Instruction, 58(March 2017), 137-147. https://doi.org/10.1016/j.learninstruc.2018.06.002

Bollen, L., van Kampen, P., \& De Cock, M. (2015). Students' difficulties with vector calculus in electrodynamics. Physical Review Special Topics - Physics Education Research, 11(2), 020129. https://doi.org/10.1103/PhysRevSTPER.11.020129

Branchetti, L., Cattabriga, A., \& Levrini, O. (2019). Interplay between mathematics and physics to catch the nature of a scientific breakthrough: The case of the blackbody. Physical Review Physics Education Research, 15(2), 020130. https://doi.org/10.1103/PhysRevPhysEducRes.15.020130

Ceuppens, S., Deprez, J., Dehaene, W., \& De Cock, M. (2018). Design and validation of a test for representational fluency of 9th grade students in physics and mathematics: The case of linear functions. Physical Review Physics Education Research, 14(2), 020105.

https://doi.org/10.1103/PhysRevPhysEducRes.14.020105

Chassy, P., \& Jones, J. (2019). The role of mathematics in the learning of physics. Journal of Mathematical and Theoritical Physics, 2(1), 8-10. https://medcraveonline.com/OAJMTP/OAJMTP-02-00045.pdf

Creswell, J. W., \& Creswell, J. D. (2017). Research design: Qualitative, quantitative, and mixed 
methods approaches (5th Ed.). SAGE Publications, Inc.

Deprez, T., Gijsen, S. E., Deprez, J., \& De Cock, M. (2019). Investigating student understanding of cross products in a mathematical and two electromagnetism contexts. Physical Review Physics Education Research, 15(2), 020132. https://doi.org/10.1103/PhysRevPhysEducRes.15.020132

Docktor, J. L., \& Mestre, J. P. (2014). Synthesis of discipline-based education research in physics. Physical Review Special Topics - Physics Education Research, 10(2), 020119. https://doi.org/10.1103/PhysRevSTPER.10.020119

Doran, Y. J. (2017). The role of mathematics in physics: Building knowledge and describing the empirical world. Onomazein, 35, 209-226. http://onomazein.letras.uc.cl/Articulos/NSFL/SFL08-Doran.pdf

Erol, M., \& Çolak, i. Ö. (2020). Mathematical modelling of electrical potential difference in a nonuniform electric field. Momentum: Physics Education Journal, 4(2), 64-72. https://doi.org/10.21067/mpej.v4i2.4440

Gifford, J. D., \& Finkelstein, N. D. (2020). Categorical framework for mathematical sense making in physics. Physical Review Physics Education Research, 16(2), 020121. https://doi.org/10.1103/PhysRevPhysEducRes.16.020121

Gosper, M., \& Ifenthaler, D. (2014). Curriculum models for the 21st century (M. Gosper \& D. Ifenthaler (eds.)). Springer New York. https://doi.org/10.1007/978-1-4614-7366-4

Hasim, N. A. B., Karim, M. M. B. A., \& Rahman, N. B. A. (2020). Aids in physics: Design and development. Momentum: Physics Education Journal, 4(2), 57-63. https://doi.org/10.21067/mpej.v4i2.4432

Hill, M., \& Sharma, M. D. (2015). Students' representational fluency at university: A cross-sectional measure of how multiple representations are used by physics students using the representational fluency survey. EURASIA Journal of Mathematics, Science and Technology Education, 11(6), 1633-1655. https://doi.org/10.12973/eurasia.2015.1427a

Hu, D., Chen, K., Leak, A. E., Young, N. T., Santangelo, B., Zwickl, B. M., \& Martin, K. N. (2019). Characterizing mathematical problem solving in physics-related workplaces using epistemic games. Physical Review Physics Education Research, 15(2), 020131. https://doi.org/10.1103/PhysRevPhysEducRes.15.020131

Husnaini, S. J., \& Chen, S. (2019). Effects of guided inquiry virtual and physical laboratories on conceptual understanding, inquiry performance, scientific inquiry self-efficacy, and enjoyment. Physical Review Physics Education Research, 15(1), 010119. https://doi.org/10.1103/PhysRevPhysEducRes.15.010119

Jensen, J. H., Niss, M., \& Jankvist, U. T. (2017). Problem solving in the borderland between mathematics and physics. International Journal of Mathematical Education in Science and Technology, 48(1), 1-15. https://doi.org/10.1080/0020739X.2016.1206979

Kjeldsen, T. H., \& Lützen, J. (2015). Interactions between mathematics and physics: The history of the concept of function-teaching with and about nature of mathematics. Science \& Education, 24(5-6), 543-559. https://doi.org/10.1007/s11191-015-9746-x

Klein, P., Dengel, A., \& Kuhn, J. (2018). Students' visual attention while solving multiple representation problems in upper-division physics. In O. Z.-T. Et (Ed.), Positive Learning in the Age of Information (pp. 67-87). Springer Fachmedien Wiesbaden. https://doi.org/10.1007/978-3-658-19567-0_6

Klein, P., Viiri, J., \& Kuhn, J. (2019). Visual cues improve students' understanding of divergence and curl: Evidence from eye movements during reading and problem solving. Physical Review Physics Education Research, 15(1), 010126. https://doi.org/10.1103/PhysRevPhysEducRes.15.010126

Kneubil, F. B., \& Robilotta, M. R. (2015). Physics teaching: Mathematics as an epistemological tool. 
Science \& Education, 24(5-6), 645-660. https://doi.org/10.1007/s11191-014-9727-5

Li, J., \& Singh, C. (2018). Investigating and improving introductory physics students' understanding of symmetry and Gauss's law. European Journal of Physics, 39(1), 015702. https://doi.org/10.1088/1361-6404/aa8d55

López-Gay, R., Martínez Sáez, J., \& Martínez Torregrosa, J. (2015). Obstacles to mathematization in physics: The case of the differential. Science \& Education, 24(5-6), 591-613. https://doi.org/10.1007/s11191-015-9757-7

Marton, F., \& Pong, W. Y. (2005). On the unit of description in phenomenography. Higher Education Research \& Development, 24(4), 335-348. https://doi.org/10.1080/07294360500284706

Mešić, V., Neumann, K., Aviani, I., Hasović, E., Boone, W. J., Erceg, N., Grubelnik, V., Sušac, A., Glamočić, D. S., Karuza, M., Vidak, A., AlihodŽić, A., \& Repnik, R. (2019). Measuring students' conceptual understanding of wave optics: A Rasch modeling approach. Physical Review Physics Education Research, 15(1), 1-20. https://doi.org/10.1103/PhysRevPhysEducRes.15.010115

Mota, A. R., Didiş Körhasan, N., Miller, K., \& Mazur, E. (2019). Homework as a metacognitive tool in an undergraduate physics course. Physical Review Physics Education Research, 15(1), 010136. https://doi.org/10.1103/PhysRevPhysEducRes.15.010136

Nielsen, S. S., \& Nielsen, J. A. (2019). A competence-oriented approach to models and modelling in lower secondary science education: Practices and rationales among danish teachers. Research in Science Education. https://doi.org/10.1007/s11165-019-09900-1

Odden, T. O. B., Lockwood, E., \& Caballero, M. D. (2019). Physics computational literacy: An exploratory case study using computational essays. Physical Review Physics Education Research, 15(2), 020152. https://doi.org/10.1103/PhysRevPhysEducRes.15.020152

Pospiech, G., Eylon, B., Bagno, E., \& Lehavi, Y. (2015). The role of mathematics for physics teaching and understanding. Conference: Mathematics in Physics Education, 3(May-June). https://doi.org/10.1393/ncc/i2015-15110-6

Pratiwi, H. Y., Hudha, M. N., Asri, M., \& Ahmad, N. J. (2019). The impact of guided inquiry model integrated with peer instruction towards science process skill and physics learning achievement. Momentum: Physics Education Journal, 3(2), 78-85. https://doi.org/10.21067/mpej.v3i2.2768

Redfors, A., Hansson, L., Hansson, Ö., \& Juter, K. (2014). The role of mathematics in the teaching and learning of physics. Ebook Proceedings of the ESERA 2013 Conference, 2, 376-383. https://www.diva-portal.org/smash/get/diva2:710055/FULLTEXT01.pdf

Redish, E. F., \& Kuo, E. (2015). Language of physics, language of math: Disciplinary culture and dynamic epistemology. Science \& Education, 24(5-6), 561-590. https://doi.org/10.1007/s11191-015-9749-7

Ryan, Q. X., Frodermann, E., Heller, K., Hsu, L., \& Mason, A. (2016). Computer problem-solving coaches for introductory physics: Design and usability studies. Physical Review Physics Education Research, 12(1), 010105. https://doi.org/10.1103/PhysRevPhysEducRes.12.010105

Saprudin, S., Liliasari, L., Setiawan, A., \& Prihatmanto, A. S. (2020). Optical Gamification (OG); Serial versus random model to improve pre-service physics teachers' concept mastery. International Journal of Emerging Technologies in Learning (IJET), 15(09), 39. https://doi.org/10.3991/ijet.v15i09.11779

Schermerhorn, B. P., \& Thompson, J. R. (2019). Physics students' construction of differential length vectors in an unconventional spherical coordinate system. Physical Review Physics Education Research, 15(1), 010111. https://doi.org/10.1103/PhysRevPhysEducRes.15.010111

Sutopo, S., \& Waldrip, B. (2014). Impact of a representational approach on students' reasoning and conceptual understanding in learning mechanics. International Journal of Science and Mathematics Education, 12(4), 741-765. https://doi.org/10.1007/s10763-013-9431-y 
Taleyarkhan, M., Dasgupta, C., Garcia, J. M., \& Magana, A. J. (2018). Investigating the impact of using a CAD simulation tool on students' learning of design thinking. Journal of Science Education and Technology, 27(4), 334-347. https://doi.org/10.1007/s10956-018-9727-3

Treagust, D. F., Duit, R., \& Fischer, H. E. (2017). Multiple representations in physics education (D. F. Treagust, R. Duit, \& H. E. Fischer (eds.); Vol. 10). Springer International Publishing. https://doi.org/10.1007/978-3-319-58914-5

Walsh, C., Quinn, K. N., Wieman, C., \& Holmes, N. G. (2019). Quantifying critical thinking: Development and validation of the physics lab inventory of critical thinking. Physical Review Physics Education Research, 15(1), 010135. https://doi.org/10.1103/PhysRevPhysEducRes.15.010135

Williams, M. (2018). The missing curriculum in physics problem-solving education. Science \& Education, 27(3-4), 299-319. https://doi.org/10.1007/s11191-018-9970-2

Young, N. T., Allen, G., Aiken, J. M., Henderson, R., \& Caballero, M. D. (2019). Identifying features predictive of faculty integrating computation into physics courses. Physical Review Physics Education Research, 15(1), 010114. https://doi.org/10.1103/PhysRevPhysEducRes.15.010114 